\title{
Differences and similarities in use and acceptance of PLEs between universities in Ecuador and Spain
}

\author{
Patricio Ricardo Humanante \\ Ramos \\ Faculty of Education, Humanities and \\ Technology, National University of \\ Chimborazo \\ Av. Eloy Alfaro \& 10 de Agosto S/N, \\ Riobamba, Ecuador \\ (+593) 32628115 ext. 2200 \\ phumanante@unach.edu.ec
}

\author{
Francisco José García Peñalvo \\ GRIAL Research Group, \\ GRIAL Research Group, $\square$ Research \\ Institute for Educational Sciences \\ (IUCE), University of Salamanca $\square$ \\ Canalejas 169, 37008, Salamanca, \\ Spain \\ (+34) 923294500 ext. 1302 \\ fgarcia@usal.es
}

\begin{abstract}
The use of the Information and Communication Technologies to learn in the educational institutions and out of them is a fact throughout the world. Educational institutions are using learning platforms to support them to manage teaching and learning processes. However students do not only use such technologies to learn in institutional contexts. They also learn during their daily life by using social networks, 2.0. tools, looking for information in the Internet, etc.; and to do so they use different devices such as smartphones. The tools and services that learners use with educational proposes, independently if they are provided by an institution, can be grouped in what is known as a Personal Learning Environment. However, it is necessary to check if these environments are used in the same way in different countries. The present work compares how Personal Learning Environments are understood and used in Ecuador and Spain and contrasts experiments carried out in universities of both countries. From this comparison it is possible to see similarities in the needs to use personal environments and to enrich the institutional ones.
\end{abstract}

\section{Categories and Subject Descriptors}

K.3.1 [Computers and Education]: Computer Uses in Education - collaborative learning, computer-assisted instruction (CAI), computer-managed instruction (CMI), distance learning.

\section{General Terms}

Human Factors

\section{Keywords}

eLearning; Information Technology and Communication (ICT); Personal Learning Environments (PLE); Virtual Learning Environments (VLE); Higher Education; Virtual Classrooms.

\section{INTRODUCTION}

The application of Information and Communication Technologies (ICT) at university contexts and specifically the use of the Learning Management Systems (LMSs) is something very common [1-4]. In the case of Spanish universities it should be noted that $91.78 \%$ use LMSs, both commercial and open solutions. A 53.80\% use Moodle [5], something normal taking into account how widespread this LMS is, with 68356 of sites, 67714248 of users across 235 countries [6].

On the other hand, the efforts of Latin American countries to integrate ICT in education have focused primarily on ensuring accessibility to mass and leverage these technologies and the potential offered in various fields and activities. For instance, in Ecuador since 2000, it is a priority to develop the infrastructure and universal access to ICTs [7], a strategy that is in a phase of implementation and monitoring. In fact, universities and polytechnics, from about five years ago, have focused their efforts to incorporate the LMS as a support to face-to-face teaching. That is, they opt for a blended-learning strategy, where face-to-face classrooms and autonomous learner work are combined [8].

However, these learning spaces developed on LMS, are not properly used. They are commonly used as mere document repositories and not taking into account methods and specific strategies for this type of training [9], which makes impossible to use all the features on interaction, personalization and adaptability that ICT provides [10].

In addition, virtual classrooms implemented on LMS, are mostly focused on the course and the institution, organized according to traditional teaching models, based on specific curricula and led by one or more instructors $[2,11]$. This means that students are constrained by the context, where they cannot develop constructive strategies and cannot use different resources tools and learning activities, from those provided by institutional environment.

It should be also noted that learning processes have a single dimension, as each person is unique, with its own limitations, strengths, interests, abilities and learning styles [10]. This requires a deep reflection on the necessity of other kind of learning environments where the student develops and reaches the knowledge. They are spaces that although were always there [12] are today specially relevant because of the incorporation of ICT. 
These new scenarios are known in the scientific and academic fields as Personal Learning Environments (PLE). Since its definition, there have been two streams to conceptualize the PLE. One defines it from a pedagogical perspective as a concept. The other considers the PLE as a technological solution to integrate several tools and services, where the users can access to different resources, tools and activities that they use in their learning.

Research on PLE and its applications, are contributing significantly to the development of education in developed countries [11, 13-29], being a fairly new topic in the rest of the world and particularly in Latin America [10, 30-32]. This is mainly because in many of these countries the technologies to implement the PLE concept are not quite widespread, both for individuals and institutions.

The idea of this paper is to compare how the PLE is understood, and how it is used and implemented in different contexts such as Spain and Ecuador. In order to do so both contexts are described and several experiments are explored and compared.

This paper is structured as follows: Section 2 includes a contextualization of how ICT is adopted by the general population, both in Ecuador and Spain, with a brief comparative analysis between the two countries. Section 3 describes the materials and methods of some research initiatives on PLE and how they are linked to the LMS. The results and discussion of the studies in both countries are presented in Section 4. Finally, in Section 5, some conclusions are posed.

\section{TECHNOLOGICAL CONTEXT OF ECUADOR AND SPAIN IN RELATION TO THE PLE}

Ecuador and Spain have a different technological landscape, that is, the way in which ICT is adopted is different. This section summarizes some these facts.

\subsection{Ecuador}

In the case of Ecuador, the latest report published by the National Institute of Statistics and Census (INEC) provides some information about ICT, and specifically ICT applied to teaching and learning processes. The December 2012 report shows the following data [33] :

- $26.40 \%$ of households have a desktop computer, while $13.90 \%$ have at least one laptop.

- $35.10 \%$ of the population has used the Internet in the last 12 months, and the $59.80 \%$ of them accesses the Internet at least once a day.

- $50.40 \%$ of the population has at least one mobile phone subscription, however only the $12.20 \%$ of the phones are smartphones

According to the above information, it is possible to see that just one in four households in Ecuador has a desktop computer, basic tool to access and process digital information. Also this report shows that Internet access is quite common and that one of every three Ecuadorian has used the Internet in the last 12 months, where currently most of the resources, information sources and networks that can be part of the PLE.

Regarding the access to the Internet and learning resources by using mobile phones, it is possible to see that one of every two Ecuadorians have a mobile phone subscription. However most of them use the mobile devices to phone people, send SMS and carry out multimedia activities (photography, video, games, etc.). Only a $12.20 \%$ of all mobile phones used by the Ecuadorians are smartphones, with which they could perform advanced tasks.

\subsection{Spain}

To analyze the case of Spain, data provided by the National Institute of Statistics (NIS) is used, specifically data for the year 2012 [34]. NIS provides the following information:

- $73.90 \%$ of households have some type of computer.

- $69.80 \%$ of people used the Internet in the last 3 months.

- $94.30 \%$ of people have used mobile phone in the last 3 months.

From this data it is possible to see that in Spain, about three out of four households own some type of computer. Regarding the use of the Internet, seven out of ten Spanish have used the Internet in the last three months, which implies a massive use of the computing resource.

With regard to the use of mobile phones, data indicates that they are very common; the $95 \%$ of Spanish have used the mobile phone in the last three months. Although the report does not provide specific information about the number of Smartphones per person, other reports says that Spain leads Europe in use of this kind of devices, with a rate of $55.20 \%$ (2012) and 66\% (2013) of users who have smartphones $[35,36]$.

Given this information, it is possible to see important differences between both countries regarding the availability of computers and mobile devices (specially when talking about smartphones), and the possibility to access to the Internet. This means that the context is different in both countries. However the policies of the Government of Ecuador included in the "National Plan for Good living" through various strategies such as: "The connectivity and telecommunications for information society and knowledge" and "The Transformation of higher education and transfer of knowledge through science, technology and innovation" [37], have been defined to increase Ecuadorians access to ICT.

These differences do not necessarily mean that the educational necessities of both countries were different. This paper presents studies at universities in both countries, with similarities on the university students perception about the importance in their learning processes of external tools. Those experiments are presented in the following section.

\section{MATERIALS AND METHODS}

This section describes different experiments in Ecuador and Spain that explore similar problems. Those experiments, although with different aims, take into account among other aspects the perception of students about the use of other tools beyond those provided by the institutions.

\subsection{Research UNACH}

As mentioned in the introduction, Ecuador Universities and Polytechnics, about five years ago, have incorporated virtual classrooms. One of them is the National University of Chimborazo, which is a public institution of Higher Education, located in the city of Riobamba capital of Chimborazo province, located $165 \mathrm{~km}$ south of Quito, capital of Ecuador.

In this university there were few studies on the effectiveness of working with virtual classrooms to support face-to-face classes 
teaching and there is not research about the relationship between these educational environments with students. Given this context a study on the "Contribution of Virtual Classrooms to Personal Learning Environments (PLE) of the students of the Career of Informatics Applied to Education of National University of Chimborazo" was carried out.

This research uses a quantitative methodology to carry out a nonexperimental study. This is because it was "performed without the deliberate manipulation of variables. It is based on the observation of phenomena in their natural environment that is later analyzed" [38]. It can be also considered as transversal and descriptive study. It is transversal because the process of data collection is carried out at one specific point in time; and descriptive because the main goal of this study is not to validate a hypothesis, but to research about the use of virtual classrooms and other learning tools used by the students of a university.

The population for this study consisted of students of the National University of Chimborazo (UNACH), Computer Science Applied to Education degree. They are studying during 12 months periods or 6 months periods. The study was carried out with students from the 12 months periods because these students have been working with LMSs during more time and their opinions about them can be more objective.

According to the institution records, students enrolled of the academic period from September 2012 - July 2013 that regularly attend to class are shown in Table 1 . As the number of students per year is not big the sum of them was considered for the experiment.

Table 1. Table number of students attending regularly enrolled in the academic year cycle mode 2012-2013. Source UNACH

\begin{tabular}{|c|c|}
\hline Grade Level & Number of students \\
\hline Third Year & 17 \\
\hline Fourth Year & 24 \\
\hline Total & 41 \\
\hline
\end{tabular}

\subsection{Research USAL}

In the University of Salamanca were carried out several experiments in order to validate de interoperability between the PLEs and the LMS. In this case two experiments are considered that try to validate different hypothesis.

In order to do so, among other methodologies, a quasiexperimental design was used [39]. This is because in those experiments pre-established groups of students (class-groups) were used, so it was not possible to have a complete randomized group of people and therefore a control study approach was not possible with either.

Quasi-experimental design implies the definition of a scientific hypothesis, from which a dependent variable is derived. Such a variable is operationalized through several assertions that are proposed to the students of both the experimental and control group (independent variable). The students grade these assertions by using a five-value levels scale $(1=$ strongly disagree, $2=$ disagree, $3=$ indifferent, $4=$ agree, $5=$ strongly agree). In both groups the same tests were applied, a pre-test at the beginning of the experiment and a post-test after it, but the students from the experimental group tested the forum widget in the PLE, while the people in the other group did not. After running the experiment, data was analysed by using probabilistic techniques to validate the scientific hypothesis.

The scientific hypothesis is accepted if the results of the pre-test are similar in both groups (which proves that both groups have a common knowledge and background) and the results of the posttest between the people involved in the experimental group and the control group are different (those who have tested the tool should answer in a different way).

In this case there are two experiments and so two hypotheses. The first one, called E1, aims to validate the following hypothesis "Enabling student to carry out activities using 2.0 web tools, while taking these into account in the institutional environment, can improve institutional knowledge about students' skills and also further their learning", it involved 40 students from the Project Management Subject distributed in a experimental and control groups [40]. The second experiment (E2), aims to validate "The exportation of functionalities from a learning platform and its use in other contexts facilitates learning personalization and therefore helps the student to learn" [41]. It consists of two pilots from education (51 students in the control group and 22 in the experimental group) and computer science (20 students in the control group and 7 in the experimental group) areas. These pilots used the same items and their results were compared looking for differences.

From the hypothesis of E1 and E2 were derived the independent variables that were operationalized through several items. These items are analysed by using different statistical techniques such as the Students' T test and the Mann Whitney U test. From the items considered this research are specially interested in the following:

- I1. I use online 2.0 tools (such as Flickr, Wordpress, Wikipedia, Slideshare, etc.) to support my learning and share information, resources and opinions with other people (E1).

- I2. I use other online tools to learn that are not included in Moodle (Youtube, Wikipedia, other forums, Slideshare, etc.) (E2).

The results of the evaluation are later endorsed with students and teachers opinions. This work compares the results related to these items with the information gathered from the experiments carried out in the UNACH.

\section{RESULTS AND DISCUSSION \\ 4.1 UNACH}

The present study has some interesting results, although it was not possible to make generalizations due to the nature of the research methodology. The idea is to guide future research on the application of ICT in teaching and learning processes, both in the degree explored, and in other of the Faculty of Education Human Sciences and Technologies, of the National University of Chimborazo.

Regarding the use of virtual classrooms, it is possible to see that $39 \%$ of the surveyed students in this study used these virtual spaces for activities outside the academic world. However, the $61 \%$ indicated that they use it only with educational purposes. 
Future surveys should explore the relationship between the use of these learning environments and: the students' learning experience, the impact on students' performance and the impact on learning quality.

As for resources provided by the virtual classrooms, over $50 \%$ of the surveyed students believed that they are enough to carry out their learning activities, even though not all students used the same resources and that they also employ other online tools (such as YouTube, Wikipedia, forums, Slideshare, etc.) to support their learning. In Figure 1 shows the results of the survey regarding these issues.

With regard to the kind of virtual classroom resources that students used more, it is possible to difference between tools for content edition and tools to interact with peers.

For content edition most of the surveyed students use desktop programs. This content is later shared through virtual classrooms. However they are beginning to use online tools for editing and publishing content.

When talking about the use of the communication tools provided by the virtual classrooms it is possible to see that most of the respondents use these channels strictly for academic purposes. Specifically some tools such as forums and chats were used just because participation in them was mandatory for students of a subject. However they do not only use these interactive tools to learn, the $82.90 \%$ uses other online resources such as social networks, this fact is shown in Figure 2.

From this experiment, it is possible to see that the virtual classrooms can contribute to define students PLEs. Because they provide students with tools for edit and publish content, tools to interact with peers and they can be seen as a meeting point for students of the same subjects and degrees. However this is not enough to define the PLE, because most of the cognitive processes and activities do not happen in these institutional environments. This is endorsed by the fact that the $83 \%$ of students that assert that virtual classrooms only manage a part of their learning activities but there are others carried out outside of them. However, the surveyed students did not agree about if what they do in such non-institutional learning activities should be taken into account for evaluation.

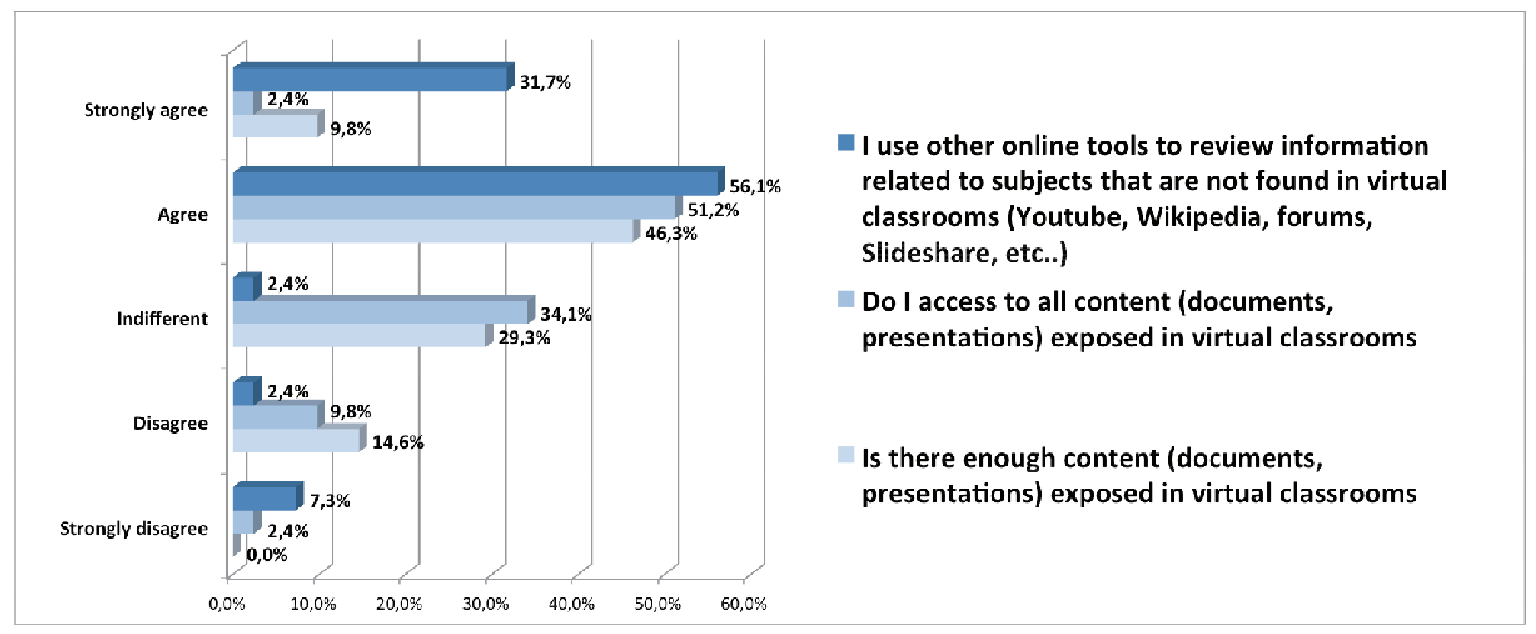

Figure 1. Information about access to tools $(n=41)$. 


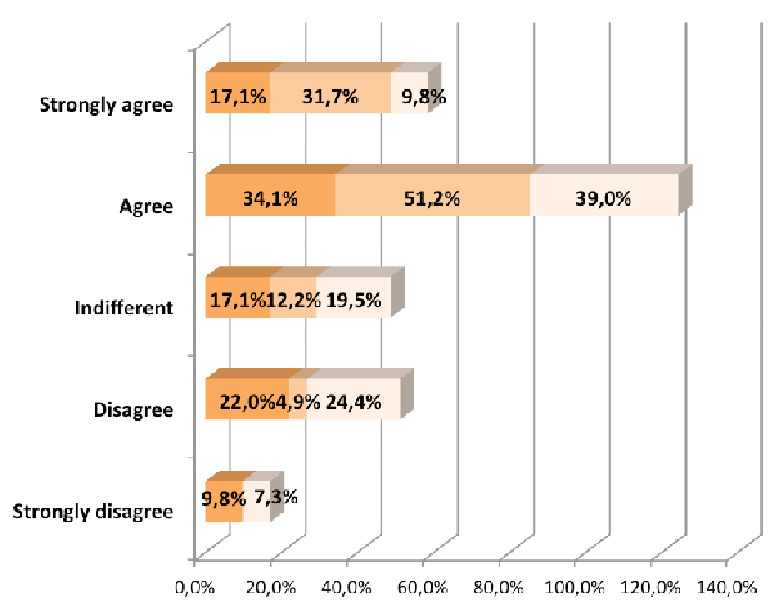

Usually use chat, messaging and virtual classrooms forums to communicate with my classmates and teachers for academic reasons only.

I use online tools chat, messaging and forums (Facebook, Twitter, Hi5, Skype, Messenger, etc..) To share information, resources and opinions with others in academic subjects more than my personal affairs.

Only use the chat forums and virtual classrooms UNACH because they are mandatory participation.

Figure 2. Relationship and communication tools $(n=41)$.

Furthermore, when surveyed students are asked about the possibility to integrate Web 2.0 tools in virtual classrooms, most of them $(95.10 \%)$, see it as very positive. Moreover the $73.20 \%$ of respondents see the possibility to access to virtual classrooms and Web 2.0. tools from mobile devices as something valuable for their learning. This is a challenge for future educational innovation projects, but they will be only possible if there is an increment in the number of students who possess or have access to a smartphone, which in this study is just a $22 \%$ of respondents.

\subsection{USAL}

The experiments carried out in the University of Salamanca also considered some of the issues explored in the UNACH.

From the E1 it was possible to validate the hypothesis from the perception of the students. It concludes that in the opinion of teachers and learners that have participated into the experiment, it is useful to include the activity carried by the students in 2.0 tools in the institutional learning environments. However for this work was especially relevant the answers of the experimental and control groups regarding I1. Regarding this item both experimental and control groups have an average value around 4 (in a five value levels Lickert's scale), which means that people from both groups think that other tools such as the Web 2.0. tools supported their learning. This item was also endorsed by students and teachers opinions. The $75 \%$ of surveyed students "would like that the activity they carry out in Flickr, Wordpress or other 2.0 online tools was taken into account from their institutional subjects; and the $100 \%$ of the teachers agreed or strongly agreed with the need to use tools other than those provided by the LMS to teach the subjects.

Regarding with the second experiment also the hypothesis was validated, and in this case in two different educational context. That is, the exportation of functionalities from a learning platform and its use in other contexts facilitates learning personalization and therefore helps the student to learn. In this case it is also important to take into account the items related to the necessity to use other tools not included in the LMS. In this case I2.
Regarding this item the average grades both for experimental and control groups of the different pilots carried out in the E2 are around 4,5 which means that most of them agree or strongly agree with the necessity to use other tools beyond the provided by the LMS.

This means that from both experiments it is possible to see that the LMS are not enough for learners, other tools such as 2.0 tools are used to learn, they could form part of the PLE, and the activity students carry out on them should be taken into account from the institution.

\subsection{Discussion}

Studies carried out in both universities have similar aspects. The experiments carried out in the UNACH and in the USAL were applied to predefined degree students. In addition both studies consider some similar issues.

The instruments used in the study of UNACH were designed with reference to the information collection instruments in the work of Conde [11], from which some changes were made according to the terminology used in the context of Ecuador University, and including the three groups of tools proposed Adell and Castaneda to structure a PLE : information access tools, tools for editing and publication of information and communication tools and relationship [28, 42].

The Ecuadorian University students support the use of Web 2.0 tools (GoogleDocs, Flickr, Wordpress, Blogger, Wikipedia, SlideShare, YouTube, Facebook, Twitter, Hi5, Skype, Messenger, etc.), to find, edit and publish content, as well as to share information, resources and reviews with others. It can be seen that $87.80 \%$ (accumulated percentage) of surveyed respondents agree or strongly agree to use these tools as a means of access to information; $75.60 \%$ (accumulated percentage) agree or strongly agree to use these tools to edit and publish content and finally $82.90 \%$ (accumulated percentage) agree or strongly agree to use these tools to connect with others in learning activities.

In the case of the Spanish University the research goes beyond descriptive studies to conduct experiments related with the use of 
other tools than provided by the LMS and the integration of the activities outcomes carried out on them. The results obtained from these experiments are quite similar to the obtained from Ecuadorian University. From the pilots carried out it is possible to see that most of students agree or strongly agree (with an average value of 4 and 4,5 in a five level value Lickerts' scale) that they use other tools to learn than the provided by the institutional. Also the teachers the $100 \%$ of the teachers agreed or strongly agreed with the need to use tools other than those provided by the LMS to teach the subjects. This means that, independently of the technological background, students both from the considered context in Ecuador and Spain use other tools than those provided by the LMSs to carry out learning activities. That is, beyond the institutional context they use other tools, decide what and when to learn, and set up they personal learning environments. In these different contexts the necessity is the same but there exist also differences.

For instance when the students were asked about the possibility of including as part of their evaluations the effort in activities that happen outside of the institutional environment, $75 \%$ of students in the Spanish University indicates that they would like to be that those outcomes were taken into account. However the case of the Ecuadorian university students just $24.40 \%$ agreed and $12.20 \%$ strongly agreed with this approach. This may be caused because some of the students of the University of Salamanca involved in the experiments (the experimental group), used a PLE, while in the Ecuadorian experiments they did not. This fact makes difficult to have a clear idea about what means to integrate outcomes into the institutional side and use, if possible, only one environment to learn.

It is clear that the experiments carried out in the Spanish university could be used as a guide to carry out future experiments in Ecuador, taking into account the lessons learned and the problems. Specially other experiments that take into account mobile environments [43-45] could be considered because of the impact of mobile technologies and the potential of this emerging market in Latino American context.

\section{CONCLUSIONS}

This paper has introduced the different perceptions about the PLE that exist between students of universities of Ecuador and Spain. These two contexts present a different level of availability and access to ICT for students. However, the use and integration of tools and necessity to go beyond the LMS is the same for students in both contexts. This means that other tools and learning environments are needed and therefore PLE concept is possible.

Several issues limit the comparison carried out in this paper: 1) The experiments do not use the same research methodology; and 2) The experiments are not considering the same hypothesis or exploring the same questions. This imply that the conclusions are only limited to a similar perception of the necessity of other tools to learn.

As a future work, new experiments should be carried out in Ecuador, the students should be able to experiment with the PLE and other possible contexts of application such as the mobile devices can be taken into account.

\section{ACKNOWLEDGMENTS}

This research work is made within University of Salamanca $\mathrm{PhD}$ Programme on Education in the Knowledge Society scope. It is partially supported by the Ministry of Education and Science of Spain (TIN2010-21695-C02) and the Goverment of Castilla y León through the project SA294A12-2.

Our thanks to the Ministry of Higher Education, Science, Technology and Innovation of the Government of Ecuador (SENESCYT) and National University of Chimborazo (UNACH) for funding to perform this research.

\section{REFERENCES}

[1] Damián, A. R., Roselló, E. G., Paz, R. I., Dacosta, J. G., and Heine, J. 2009. Las TIC en la educación superior: estudio de los factores intervinientes en la adopción de un LMS por docentes innovadores. Rev. Latinoam. Tecnol. Educ. - RELATEC, 8, 1 (Jul. 2009), 35-51.

[2] Downes, S. 2005. E-learning 2.0. eLearn Magazine an ACM Publication (Oct. 2005). [Online]. Available: http://elearnmag.acm.org/featured.cfm?aid=1104968. [Accessed: 08-Mar-2014].

[3] Llamas-Nistal, M., Caeiro-Rodriguez, M., and Castro, M. 2011 Use of E-Learning Functionalities and Standards: The Spanish Case, IEEE Trans. Educ. 54, 4 (Nov. 2011), 540-549.

[4] Llamas, M., Caeiro, M., Castro, M., Plaza, I., and Tovar, E. 2011. Use of LMS Functionalities in Engineering Education. In Proceedings of the 2011 Frontiers in Education Conference (2011). FIE, Washington, DC, USA, S1G-1-1-S1G-6.

[5] Prendes, M. P. 2009. PLATAFORMAS DE CAMPUS VIRTUAL CON HERRAMIENTAS DE SOFTWARE LIBRE: Análisis comparativo de la situación actual en las universidades españolas. Report of Project EA-2008-0257. University of Murcia. [Online]. Available: http://www.um.es/campusvirtuales/informe.html

[6] Moodle. 2014. Estadísticas de Moodle. Moodle WebSite (Mar. 2014). [Online]. Available: https://moodle.org/stats/.

[7] Villatoro, P., and Silva, A. 2005. Estrategias, programas y experiencias de superación de la brecha digital y universalización del acceso a las nuevas tecnologías de información y comunicación (TIC): un panorama regional. United Nations Publications.

[8] Bonk, C. J., and Graham, C. R. 2012. The Handbook of Blended Learning: Global Perspectives, Local Designs. John Wiley \& Sons.

[9] García Peñalvo, F. J. 2008. Advances in E-Learning: Experiences and Methodologies. London: IGI Global.

[10] Humanante Ramos, P. R., and García Peñalvo, F. J. 2013. Aporte de las Aulas Virtuales a los Entornos Personales de Aprendizaje (PLE) de los estudiantes de la Carrera de Informática Aplicada a la Educación de la Universidad Nacional de Chimborazo. (Jun. 2013). [Online]. Available: http://gredos.usal.es/jspui/handle/10366/121996. [Accessed: 20-Jan-2014].

[11] Conde, M. A. 2012. Personalización del aprendizaje: Framework de servicios para la integración de 
aplicaciones online en los sistemas de gestión del aprendizaje. Doctoral Thesis. University of Salamanca [Online]. Available: http://www.tesisenred.net/handle/10803/84752. [Accessed: 23-Jan-2014]

[12] Castañeda, L., and Adell, J. 2013. La anatomía de los PLEs. In Entornos Personales de Aprendizaje: Claves para el ecosistema educativo en red, Castañeda, L. \& Adell, J., Alcoy: Marfil. 11-27.

[13] Wilson, S., Liber, O., Johnson, M., Beauvoir, P., Sharples, P., and Milligan, C. 2009. Personal Learning Environments: Challenging the dominant design of educational systems. J. E-Learn. Knowl. Soc. - Engl. Version. 3, 2, (Nov. 2009), 27-38.

[14] Cabero Almenara, J., Barroso Osuna, J., and Llorente Cejudo, M. C. 2010. El diseño de Entornos Personales de Aprendizaje y la formación de profesores en TIC. Digit. Educ. Rev. 0, 18 (Dec. 2010), 27-37.

[15] Castaneda, L., and Soto, J. 2010. Building Personal Learning Environments by Using and Mixing ICT Tools in a Professional Way. Digit. Educ. Rev. 18 (Dec. 2010), 925.

[16] Santamaria, F. 2010. Evolución y desarrollo de un Entorno Personal de Aprendizaje en la Universidad de León. Digit. Educ. Rev. 0, 18 (Dec. 2010), 48-60.

[17] Ebner, M., and Taraghi, B. 2010. Personal Learning Environment for Higher Education - A First Prototype. World Conf. Educ. Multimed. Hypermedia Telecommun. 1 (Jun. 2010), 1158-1166.

[18] Garcia-Penalvo, F. J., Conde, M. A., Alier, M., and Casany, M. J. 2011. Opening Learning Management Systems to Personal Learning Environments. J. Univers. Comput. Sci. 17, 9, 1222-1240.

[19] Moccozet, L. 2012. Introducing learning performance in personal learning environments. In Proceedings of the 12th IEEE International Conference on Advanced Learning Technologies (ICALT 2012). 702-703.

[20] Dabbagh, N., and Kitsantas, A. 2012. Personal Learning Environments, social media, and self-regulated learning: A natural formula for connecting formal and informal learning. Internet High. Educ. 15, 1(Jan. 2012), 3-8.

[21] Kravcik, M., and Klamma, R. 2012. Supporting selfregulation by personal learning environments. In Proceedings of the 12th IEEE International Conference on Advanced Learning Technologies (ICALT 2012). 710711.

[22] Alharbi, M. T., Platt, A., and Al-Bayatti, A. H. 2012. Context-aware Personal Learning Environment. In Proceedings of the 7th International Conference for Internet Technology and Secured Transactions (ICITST2012). 692-697.

[23] Arquero, J. L., and Romero-Frias, E. 2012. Approaches to Learning and Perceived Usefulness of Personal Learning Environments. Proceedings of the 5th International Conference of Education, Research and Innovation (ICERI2012, Madrid, November 19-21, 2012). 4220-4229.

[24] García Peñalvo, F. J., Conde González, M. Á., and Moreno García, M. N. 2013. Implementación y aplicación de un entorno personalizado de aprendizaje móvil en el contexto de las asignaturas de Ingeniería del Software. (Jun. 2013). [Online]. Available: http://gredos.usal.es/jspui/handle/10366/122715. [Accessed: 28-Feb-2014].

[25] Kop, R., and Foumier, H. 2013. Developing a framework for research on personal learning environments. ELearning Pap. 35 (Nov. 2013). [Online]. Available: $\mathrm{http}: / / w w w . o p e n e d u c a t i o n e u r o p a . e u /$ en/article/Developinga-framework-for-research-on-Personal-LearningEnvironments-?paper=133343. [Accessed: 28-Feb-2014].

[26] Leone, S. 2013. Characterisation of a Personal Learning Environment as a Lifelong Learning Tool. New York: Springer.

[27] Casquero, O., Ovelar, R., Romo, J., Benito, M., and Alberdi, M. 2013. Students' personal networks in virtual and personal learning environments: a case study in higher education using learning analytics approach. Interactive Learning Environments. (Jul. 2013). DOI= http://www.tandfonline.com/doi/abs/10.1080/10494820.20 13.817441 .

[28] Castañeda, L., and Adell, J. 2013. ENTORNOS PERSONALES DE APRENDIZAJE: CLAVES PARA EL ECOSISTEMA EDUCATIVO EN RED. Alcoy: Marfil.

[29] Marín Juarros, V., Salinas Ibáñez, J., and De Benito Crosetti, B. 2014. Research results of two personal learning environments experiments in a higher education institution. Interact. Learn. Environ. 22, 2, 205-220.

[30] Fonseca, D. E. L. 2011. EduCamp Colombia: Social Networked Learning for Teacher Training. Int. Rev. Res. Open Distance Learn. 2, 3 (Mar. 2011), 60-79.

[31] Barrios, W., Fernández, M., Godoy, M., and Mariño, S. 2012. De Moodle a Entornos Personales de Aprendizaje (PLE). SSI 2012. 8, 93-104.

[32] Ampudia Rueda, V., and Trinidad Delgado, L. H. 2012. Entornos Personales de Aprendizaje: ¿final o futuro de los EVA?. Journal Reencuentro. 63, 32-39.

[33] INEC. 2012. TIC 2012 ECUADOR. Technical Report. National Institute of Statistics and Censuses of Ecuador [Online]. http://www.inec.gob.ec/sitio_tics2012/

Available:

[34] INE. 2012. Encuesta sobre Equipamiento y Uso de Tecnologías de la Información y Comunicación en los hogares 2012. National Statistics Institute of Spain. [Online]. Available: http://www.ine.es/jaxi/menu.do?type=pcaxis\&path=/t25/p4 50/a2012\&file $=$ pcaxis.

[35] Europa Press. 2012. España lidera el uso de 'smartphones' en Europa - 20minutos.es. 20 minutos. (April 06, 2012).

[36] Europa Press 2013. España lidera en Europa en uso de 'smartphones' con un $66 \%$ de tasa de penetración 20minutos.es. 20 minutos. (August 21, 2013).

[37] SENPLADES. 2009. Plan Nacional del Buen Vivir. Technical Report. National Secretary of Planning and Development of Ecuador. [Online]. Available: http://plan.senplades.gob.ec. 
[38] Hernández, R., Fernández, C., and Baptista, P. 2010. Metodología de la investigación. México DF: McGrawHill.

[39] Campbell, D. T., and Stanley, J. C. 1963. Experimental and Quasi-Experimental Design for Research. Boston: Houghton Mifflin.

[40] Conde, M. Á., García-Peñalvo, F. J., Rodríguez-Conde, M. J., Alier, M., Casany, M. J., and Piguillem, J. 2014. An evolving Learning Management System for new educational environments using 2.0 tools. Interact. Learn. Environ. 22, 2, 188-204.

[41] Conde González, M. Á., Garcia-Penalvo, F. J., Alier, M., and García-Holgado, A. 2014. The learners' and teachers' perception of LMS openess in educational and technological areas. Comput. Hum. Behav. 31, 517-526.

[42] Adell, J., and Castañeda, L. 2010. Los Entornos Personales de Aprendizaje (PLEs): una nueva manera de entender el aprendizaje. In Roig Vila, R., \& Fiorucci, M. (Eds.) Claves para la investigación en innovación y calidad educativas. La integración de las Tecnologías de la Información y la
Comunicación y la Interculturalidad en las aulas. Alcoy: Marfil - Roma TRE Universita degli studi.

[43] Casany, M. J., Alier, M., Mayol, E., Piguillem, J., Galanis, N., García-Peñalvo, F. J., and Conde, M. A. 2012. Moodbile: A framework to integrate m-learning applications with the LMS. J. Res. Pract. Inf. Technol. 44, 2, 41-61.

[44] Conde, M. A., García-Peñalvo, F. J., Alier, M., and Piguillem, J. 2012. How to Define and Apply Mobile Personal Learning Environments. In Proceedings of the 1st International Workshop on Interaction Design in Educational Environments. (IDEE 2012 in Conjunction with ICEIS 2012). Wroclaw, Poland, 57-66.

[45] Conde, M. A., Garcia-Penalvo, F. J., Alier, M., and Piguillem, J. 2013. The Implementation, Deployment and Evaluation of a Mobile Personal Learning Environment. $J$. Univers. Comput. Sci. 19, 7, 854-872. 